\title{
Political regimes and sovereign credit risk in Europe, I750-I9I3
}

\author{
MARK DINCECCO \\ Department of Economics, IMT Lucca Institute for Advanced Studies, Piazza \\ San Ponziano 6, Lucca, Italy, 55I00, m.dincecco@imtlucca.it
}

\begin{abstract}
This article uses a new panel data set to perform a statistical analysis of political regimes and sovereign credit risk in Europe from I750 to I9I3. Old Regime polities typically suffered from fiscal fragmentation and absolutist rule. By the start of World War I, however, many such countries had centralized institutions and limited government. Panel regressions indicate that centralized and/or limited regimes were associated with significant improvements in credit risk relative to fragmented and absolutist ones. Structural break tests also reveal close relationships between major turning points in yield series and political transformations.
\end{abstract}

\section{Introduction}

This article examines the relationship between political regimes and sovereign credit risk over the long run. The chosen period, I750-I913, captures key transformations to European political institutions. Study of the process of financial development in Europe is also valuable because countries around the world have implemented its forms of fiscal governance. ${ }^{\mathrm{I}}$ An understanding of the European growth experience thus translates into useful lessons for emerging economies today.

Our framework for analysis follows Dincecco (2009a) and consists of two core elements. The first comes from North and Weingast (I989). They claim that institutional reforms with the Glorious Revolution of I688 allowed the English crown to make a credible commitment to responsible debt service. ${ }^{2}$ Since the new constitution gave parliament a regular right to monitor spending decisions, the executive could keep promises to execute

\footnotetext{
I See, for instance, La Porta, Lopez-de-Silanes, Shleifer and Vishny (1997, 1998, 1999) and La Porta, Lopez-de-Silanes and Shleifer (2008).

${ }^{2}$ Also see Dickson (I967), Jones (I972), Stone (I979) and Hill (I980). It is debatable whether political changes associated with the Glorious Revolution actually improved property rights protections. Clark (I996) argues that secure property rights existed in England from I600 while O'Brien (200I) claims that England implemented key constitutional and administrative structures in the I640s. Moreover, Sussman and Yafeh (2006) find that the reforms of I688 did not significantly lower British capital costs over the next century. Yet scholars often use North and Weingast's work as a point of departure.
} 
fiscal plans in time-consistent ways. ${ }^{3}$ The second part comes from Epstein (2000). He argues that institutional fragmentation within countries and not fiscal abuse by rulers was the fundamental cause of fiscal distortions prior to the $1800 .^{4}$ In fragmented polities, there was a close relationship between local tax control and political autonomy. Thus, elites had strong incentives to oppose structural reforms that threatened traditional rights. The result was a classic public goods problem, since each locality wished to free ride on the tax contributions of others. Dincecco (2009a) finds that per-capita revenues collected by fragmented sovereignties were low. A lack of resources made it difficult for national governments to repay debts. Centralized from medieval times, England - the example that North and Weingast proffer was exceptional. 5

I argue that the political transformations identified by North and Weingast and Epstein were complementary rather than competing elements of sound fiscal policy. By I913, many European countries had struck an institutional balance that allowed national governments to gather enough in tax revenues while limiting executive discretion over expenditures. To evaluate my hypothesis, I adopt a systematic approach that examines the effects of political reforms on sovereign credit risk both within and across European polities. My investigation thus complements case study texts by Hoffman and Norberg (1994), Bonney (I999), Bordo and Cortés-Conde (200I) and others. ${ }^{6}$

I first construct a new panel data set on government bond yields for II European countries. Long yearly series of relevant fiscal data characterize group I, which includes many of the largest and/or most important players

See, among others, Frey and Kucher (2000), Sussman and Yafeh (2000, 2006), Quinn (200I), Stasavage (2003, 2005) and Summerhill (2004).

${ }^{3}$ Several works use the concept of credible commitment to explain macroeconomic differences between eighteenth-century rivals Britain and France. These include Mathias and O’Brien (1976), Weir (1989), Hoffman and Norberg (1994), Rosenthal (I998), O'Brien (200I) and White (200I).

4 Also see Brewer (1989), Henshall (1992), Hoffman and Norberg (1994), Hoffman and Rosenthal (1997), Rosenthal (I998) and O'Brien (200I).

${ }^{5}$ Brewer (1989), Sacks (1994), Epstein (2000) and O’Brien (2001).

${ }^{6}$ Qualitative comparative studies of European fiscal history include Tilly (I990), Bonney (I995) and O'Brien (200I). There exists a 'sister' cross-country literature on the political economy of international bond markets during the classic gold standard era. See, for instance, Flandreau and Zumer (1994), Bordo and Rockoff (1996), Obstfeld and Taylor (2003), Ferguson (2006) and Ferguson and Schularick (2006). By the I870s, however, most European governments were administratively centralized democracies. For an earlier era, Stasavage (2005) also examines the politics of sovereign debt in Europe. One advantage of the present work is that it employs market-determined rather than nominal yields, which provide direct measures of investor perceptions of credit risk. Other papers that use historical bond series to measure the impact of economic and political factors on fiscal performance include Mauro, Sussman and Yafeh (2002), Mitchener and Weidenmier (2005) and Brown, Burdekin and Weidenmier (2006). 
in Europe at the time: England, France, the Netherlands, Prussia, and Spain. The second group (Austria-Hungary, Belgium, Denmark, Italy, Portugal, and Sweden) has shorter data series. I then classify political regimes according to Dincecco (2009a). Fiscal centralization was typically the result of French conquest from I 789 to I8I5. Limited government generally took place decades after centralization during the 1800 .

The statistical framework that I use is innovative in that it consists of two components not often employed together: regressions on the panel data set and structural break tests. The regressions incorporate a relevant set of control variables (violent conflict, economic growth, and fiscal and monetary policy) to assess the effects of political regimes on sovereign credit risk. For robustness, I include structural break tests that assume no a priori knowledge of major turning points. The statistical inquiry supports the argument that political transformations towards centralized and limited regimes led to significant creditworthiness improvements.

The rest of the paper proceeds as follows. Section 2 examines the relationship between political regimes and creditworthiness. Section 3 describes the data and sample countries. Section 4 examines the data on a case-by-case basis. Section 5 discusses the statistical framework. Section 6 presents the statistical results. Section 7 concludes.

\section{Political regimes and sovereign risk}

\section{I. Historical overview}

This section describes the relationship between political arrangements and sovereign credit risk. The classification of political regimes follows Dincecco (2009a), who argues that national governments completed the process of fiscal centralization the year that they began to secure revenues by way of a tax system with uniform rates throughout the country. Dincecco claims that limited government emerged the year in which parliament gained the constitutional right to control the national budget on an annual basis. For stability, parliament's power of the purse had to hold for at least two consecutive decades.

Tables I and 2 reproduce Dincecco's dates for fiscal centralization and limited government. The first table indicates that fiscal centralization took place swiftly and permanently throughout much of the Continent from 1789 onwards. The National Assembly transformed the tax system in France by eliminating traditional exemptions and privileges. Napoleon completed this process after his coup in 1799. French conquest of Belgium, the Dutch Republic and several Italian polities led to significant tax reforms. After defeat in battle by France in I806, Prussia also made major fiscal innovations. The second table indicates that limited government reforms began during 
Table I. Fiscal centralization in Europe

\begin{tabular}{|c|c|c|c|}
\hline & & Year & Event \\
\hline \multirow[t]{5}{*}{ Group I } & England & I066 & $\begin{array}{l}\text { Norman conquest and subsequent } \\
\text { erosion of provincial authority }\end{array}$ \\
\hline & France & $\mathrm{I} 790$ & $\begin{array}{l}\text { Administrative reforms after Revolution } \\
\text { of } 1789\end{array}$ \\
\hline & Netherlands & I 806 & $\begin{array}{l}\text { Administrative reforms under French } \\
\text { control (I795-I8I3) }\end{array}$ \\
\hline & Prussia & I 806 & $\begin{array}{l}\text { Administrative reforms after defeat in } \\
\text { battle by French in } 1806\end{array}$ \\
\hline & Spain & I 844 & $\begin{array}{l}\text { Administrative reforms during } \\
\text { 'Moderate' decade of } \mathrm{I} 84 \mathrm{OS}\end{array}$ \\
\hline \multirow[t]{6}{*}{ Group 2} & Denmark & I688 & Establishment of official cadastre system \\
\hline & Belgium & I 795 & $\begin{array}{l}\text { Administrative reforms after French } \\
\text { annexation in } 1795\end{array}$ \\
\hline & Portugal & 1832 & $\begin{array}{l}\text { Administrative reforms during } \\
\text { Revolutionary era (I820-5I) }\end{array}$ \\
\hline & Sweden & I 840 & 'Departmental' reforms \\
\hline & Austria-Hungary & I 848 & $\begin{array}{l}\text { Administrative reforms during Year of } \\
\text { Revolutions }\end{array}$ \\
\hline & Italy & I86I & $\begin{array}{l}\text { Establishment of Kingdom and } \\
\text { subsequent fiscal unification }\end{array}$ \\
\hline
\end{tabular}

Source: Dincecco (2009a).

Notes: The first column lists sample countries by group. Long annual data series over a variety of political regimes characterize group I, which includes the largest and/or most important players in Europe at the time. Group 2 has shorter data series. The second column displays the year that fiscal centralization was completed. The final column offers brief 'explanations' for the dates.

the I830s and I840s, several decades after centralization. A second wave occurred in the I860s and 1870 .

Some exceptions bear mention. At one extreme, England had centralized institutions and parliamentary government long before most Continental regimes. At the other, the French failed in their attempts to make administrative changes in Iberia: fiscal centralization in Portugal and Spain did not happen until 1832 and I844, respectively. Though political risks and instability dominated the peninsula over the I80os, stable limited regimes were established in Portugal in I85I and in Spain in 1876.

\subsection{Theoretical implications}

By establishing parliament's power of the purse, limited government reduced the likelihood of poor spending choices by executives. Ceteris paribus, it should have improved sovereign credit risk, as expressed by a reduction in yield spreads over benchmark British consols, relative to absolutist regimes. The relationship between fiscal centralization and credit risk is less 
Table 2. Limited government in Europe

\begin{tabular}{|c|c|c|c|}
\hline & & Year & Event \\
\hline \multirow[t]{6}{*}{ Group I } & Netherlands & I572 & Formation of Dutch Republic (I572-I795) \\
\hline & & I 848 & Implementation of new constitution \\
\hline & England & I688 & Establishment of constitutional monarchy \\
\hline & Prussia & I 848 & Establishment of constitutional monarchy \\
\hline & France & 1870 & $\begin{array}{l}\text { Establishment of stable constitutional } \\
\text { regime }\end{array}$ \\
\hline & Spain & I876 & $\begin{array}{l}\text { Establishment of stable constitutional } \\
\text { monarchy }\end{array}$ \\
\hline \multirow[t]{6}{*}{ Group 2} & Denmark & None & $\begin{array}{l}\text { Absolutism restored (I } 866 \text { ) after } \\
\text { short-lived constitutional regime }\end{array}$ \\
\hline & Belgium & I83I & Established as a constitutional monarchy \\
\hline & Portugal & $185 \mathrm{I}$ & $\begin{array}{l}\text { Establishment of stable constitutional } \\
\text { monarchy }\end{array}$ \\
\hline & Italy & I86I & Established as a constitutional monarchy \\
\hline & Sweden & I866 & $\begin{array}{l}\text { Dissolution of Estates and introduction of } \\
\text { bicameral legislature }\end{array}$ \\
\hline & Austria-Hungary & I867 & Establishment of constitutional monarchy \\
\hline
\end{tabular}

Source: Dincecco (2009a).

Notes: The first column lists sample countries by group, which Table I describes. The second column displays the year that limited government emerged. The final column offers brief 'explanations' for the dates.

straightforward. On one hand, centralization generated a significant increase in per-capita revenues (see Dincecco 2009a), which made it easier for crowns to follow sound fiscal policies. Thus, credit risk should have fallen. On the other hand, consolidation of fiscal powers by monarchs may have aggravated problems of executive control. There was always the danger that executives would waste new revenues on ill-advised wars. If so, then credit risk should have increased after centralization.

Table 3 summarizes the sovereign credit risk characteristics of the four possible political regimes: fragmented and absolutist, centralized and absolutist, fragmented and limited, and centralized and limited. Note that there was only one example of the fragmented and limited regime among sample countries. ${ }^{7}$ Credit risk under centralized and limited regimes should have been lower than under fragmented and absolutist ones. By eliminating local free riding, fiscal centralization implied an increase in public funds. Similarly, limited government established spending constraints on executives. The combination of greater revenues and parliamentary control should have improved credit risk.

By the same logic, credit risk should have decreased under fragmented and limited regimes in comparison with fragmented and absolutist ones. Theory cannot predict if there was an improvement in credit risk under centralized

7 This was the Dutch Republic (I572-I795). For additional details, see Section 4. 
Table 3. Sovereign credit risk characteristics of political regimes

\begin{tabular}{ll}
\hline \hline Regime & Government bond yields \\
\hline Fragmented and absolutist & $\begin{array}{c}\text { High due to local free-riding and lack of } \\
\text { credible commitment } \\
\text { Centralized and absolutist } \\
\text { Decrease due to resolution of local free-riding but } \\
\text { still no credible commitment } \\
\text { Fecrease due to credible commitment but still } \\
\text { local free-riding }\end{array}$ \\
Centralized and limited & $\begin{array}{c}\text { Low due to resolution of local free-riding and } \\
\text { credible commitment }\end{array}$ \\
\hline \hline
\end{tabular}

Sources: See text.

and absolutist regimes in comparison with fragmented and absolutist ones, since fiscal centralization generated additional funds that executives may have used to repay debts or spent recklessly. However, we may say definitively that credit risk under centralized and limited regimes should have been the lowest of all, since both sorts of fiscal problems had been resolved.

\section{Data and sample countries}

I assembled a database on long-term government bonds in Europe from 1750 to I913. Appendix I documents the data sources and construction methods for each sample country. Since bond prices often exhibited high volatility, the use of annual data (i.e. one observation per year) increases the likelihood of misrepresenting yield trends. To avoid this possibility, I calculated yearly averages of weekly or monthly data. The yield series came in large part from secondary sources such as the Global Financial Database (GFD), which offered high-frequency data. For accuracy, I compared the GFD series that I computed with annual data from Homer and Sylla (I99I).

The historical nature of the yield series merits special attention. To begin, demand for sovereign bonds was not integrated or elastic. Governments faced different domestic and international opportunities to market their debts. As Appendix I describes, bonds for group I countries were typically traded on home exchanges, whereas bonds for group 2 countries were traded on the London Stock Exchange. Prior to I815, most governments did not offer a public asset comparable to the British consol (i.e. perpetual, dominant, easily negotiable and relatively risk-free), but instead issued a multitude of debt instruments, each subject to different terms and conditions. In such cases, I chose the sovereign bond that best captured long-term yield levels. Appendix I provides the details.

The sample was divided into two groups based on data availability and historical importance. Annual published series of nearly a century or more for government bonds as well as for a variety of controls typically existed for the five polities (England, France, the Netherlands, Prussia and Spain) 
that comprised the first set. Not only were these countries among the largest and/or most powerful players in Western Europe at the time, but for them data were also available over a variety of political regimes.

Shorter published time series existed for the six countries (AustriaHungary, Belgium, Denmark, Italy, Portugal and Sweden) in the second group. Data for Belgium and Italy only began after they were founded as constitutional monarchies in I83I and I86I, respectively. Annual series for Austria-Hungary, Portugal, and Sweden did not start until after the establishment of centralized and limited regimes during the $1800{ }^{8}{ }^{8}$ Since Denmark did not achieve a stable form of constitutional government by 1913, it functioned as an additional 'absolutist' control in the regressions. Though data prior to political transformations were not available for the second set of countries, their inclusion enriched the sample by expanding the range of institutional experiences.

\section{Case studies}

Table 4 displays the summary statistics for the yield panel. ${ }^{9}$ In total, there are 864 observations, 62 for fragmented and absolutist regimes, 294 for centralized and absolutist ones, and 492 for centralized and limited ones; I6 observations characterize the lone fragmented and limited regime. One immediately notices that average yields associated with centralized and absolutist regimes (5.4I percent) and centralized and limited ones (4.52 percent) were low relative to fragmented and absolutist ones (7.20 percent). Average yields for the fragmented and limited regime (3.09 percent) were also much lower. ${ }^{\text {IO }}$

Before moving on to the statistical analysis, it is worthwhile to study France and the Netherlands, two sample polities for which long data series are available. Figure I, which plots yield spreads between French long-term government bonds and British consols from I750 to I9I3, indicates that yield

${ }^{8}$ Though Ferguson (2006) collected yield data for Austria-Hungary from I844 onwards, the series was discontinuous through 1870 . My yield series for Austria-Hungary began in 1874. Following Dincecco (2009a, 2009b), I designated Portugal as a group 2 country. However, it differed from other group 2 countries because its yield series began in I823, before fiscal centralization and limited government. In Section 4, I analyze the Portuguese case in the same way as for group I countries. I also perform the structural break tests for Portugal in Section 6. Continuous Portuguese revenue and expenditure series did not begin until I852. Since the regression analysis used budgetary data as an economic control, Portuguese yield observations prior to political transformations were lost. Yet econometric specifications that excluded budgetary data and hence used the entire Portuguese yield series did not significantly alter the findings.

${ }^{9}$ I followed Ferguson and Schularick (2006) and excluded I6 observations with yields of 20 percent or more from the econometric analysis. These were the Netherlands, I8I I, I813, and Spain, I824-33, I876-9. However, the regression results were robust to specifications that included all observations.

Io This was the Dutch Republic, which I discuss below. 
Table 4. Summary statistics of yield data (as percents per year)

\begin{tabular}{lrlllr}
\hline \hline & Obs. & Mean & St. dev. & Min & Max \\
\hline All regimes & 864 & 4.76 & I.95 & $2.4 \mathrm{I}$ & I6.I9 \\
Fragmented and absolutist & 62 & 7.20 & 3.09 & 3.34 & I5.65 \\
Centralized and absolutist & 294 & $5.4 \mathrm{I}$ & 2.10 & 3.27 & I6.19 \\
Fragmented and limited & $\mathrm{I} 6$ & 3.09 & 0.53 & $2.4 \mathrm{I}$ & 4.33 \\
Centralized and limited & 492 & 4.52 & I.43 & 2.45 & 16.15 \\
\hline \hline
\end{tabular}

Sources: See Appendix I.

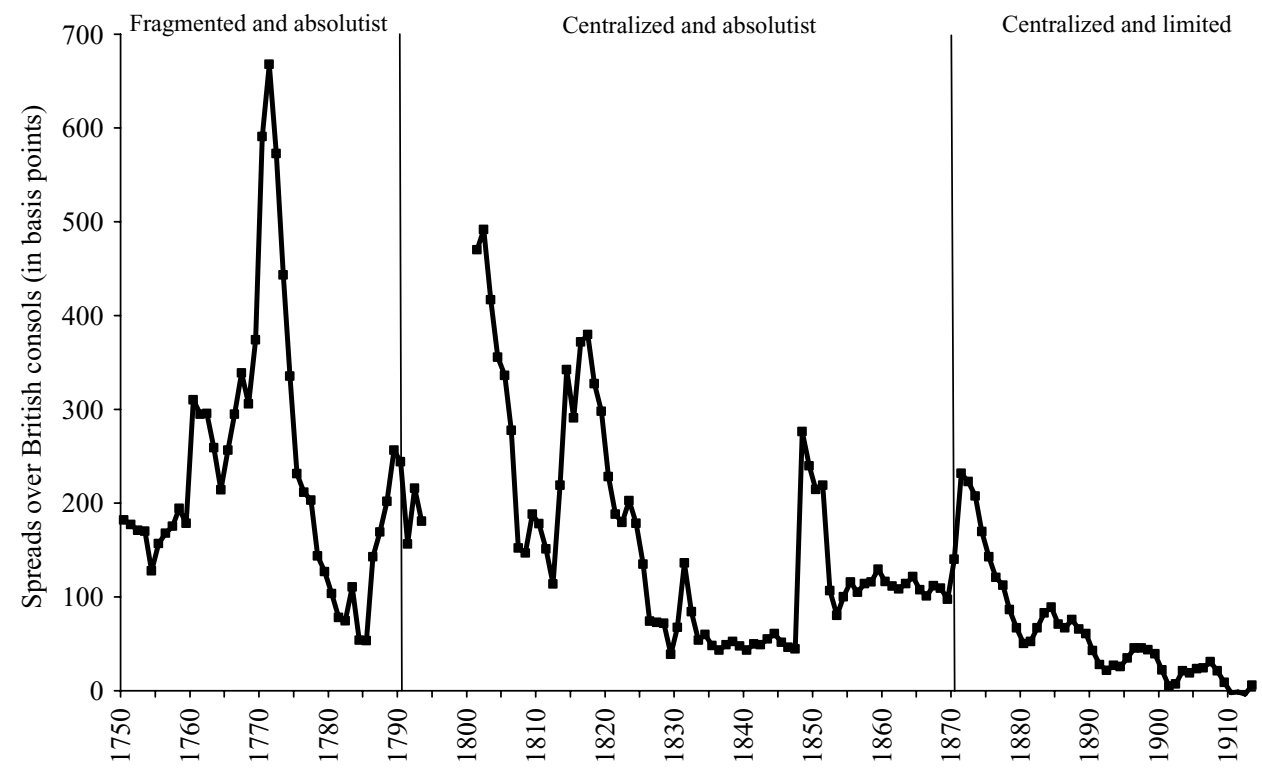

Figure I. Yield spreads, France, I750-I9I3

Sources: See Appendix I.

spreads were typically 200 basis points or more under the fragmented and absolutist regime. The French Revolution (I789-99) led to the establishment of a national tax system with uniform rates. Spreads remained high through the end of the Napoleonic Wars. Unlike the eighteenth century, however, France no longer defaulted on its debts. ${ }^{\text {II }}$

French yield spreads decreased after I8I5. The short-lived constitutional 'July' regime (1830-47) saw spreads that were less than 50 basis points. ${ }^{12}$ Under the authoritarian regime of Napoleon III (I85I-70), however, they doubled to over Ioo basis points. Spreads fell steadily after the establishment

${ }^{11}$ Defaults prior to 1789 occurred in I715, I759 and I770. See Sargent and Velde (I995).

${ }^{12}$ The 1830 regime was not classified as limited because it endured for less than two decades. However, I categorized it as such for one of the robustness checks in Section 6. 


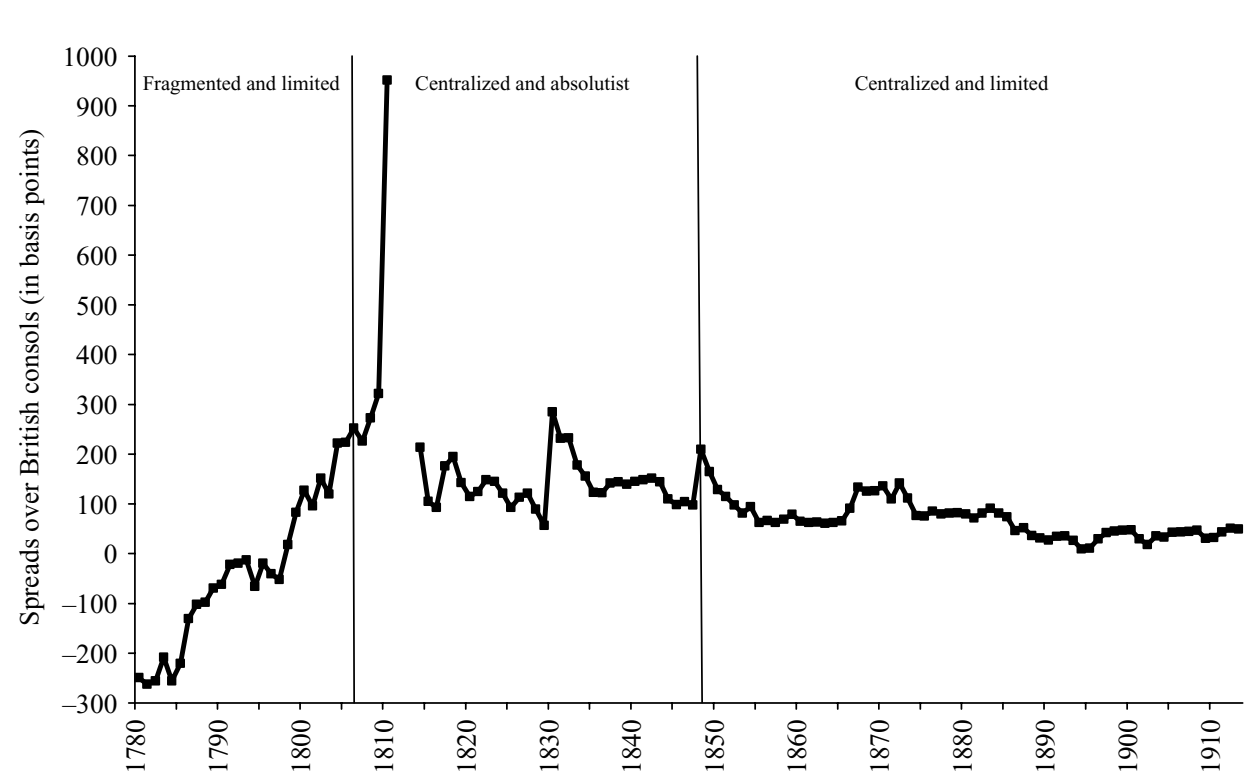

Figure 2. Yield spreads, Netherlands, I780-1913

Sources: See Appendix I.

of a stable centralized and limited regime in 1870 . By the start of the I890s, they neared zero.

Figure 2 plots yield spreads in basis points between Dutch long-term government bonds and British consols from I780 to 1913. I followed Dincecco's (2009a) classification of the political regime in the Dutch Republic (I572-1795) as fragmented and limited. By investing heavily in government bonds, ruling elites aligned lender and borrower incentives and provided a credible commitment to repay debts. Figure 2 highlights the success of this mechanism. Since the Republic received loans at lower rates of interest than Britain, spreads at the start of the 1780 s were negative. Van Zanden and van Riel (2004), however, argue that widespread fiscal fragmentation hindered the ability of the Republic to raise funds and service debts. Indeed, spreads rose quickly in the years before the French conquered the Netherlands in $1795 .{ }^{13}$

The I8I5 constitution granted absolutist control to King Willem I, who came to power at the end of the Napoleonic era. Parliamentary budget authority, promulgated at Io-year intervals, was ineffective. Spending heavily on the military, on infrastructure, and on the monarchy itself, Willem was unable to balance the national accounts, though fiscal centralization

${ }^{13}$ Also see Fritschy and van der Voort (1997), t'Hart (1997), Fritschy, t'Hart and Horlings (200I), van Zanden and van Riel (2004), van Zanden and Prak (2006) and Fritschy (2007). 


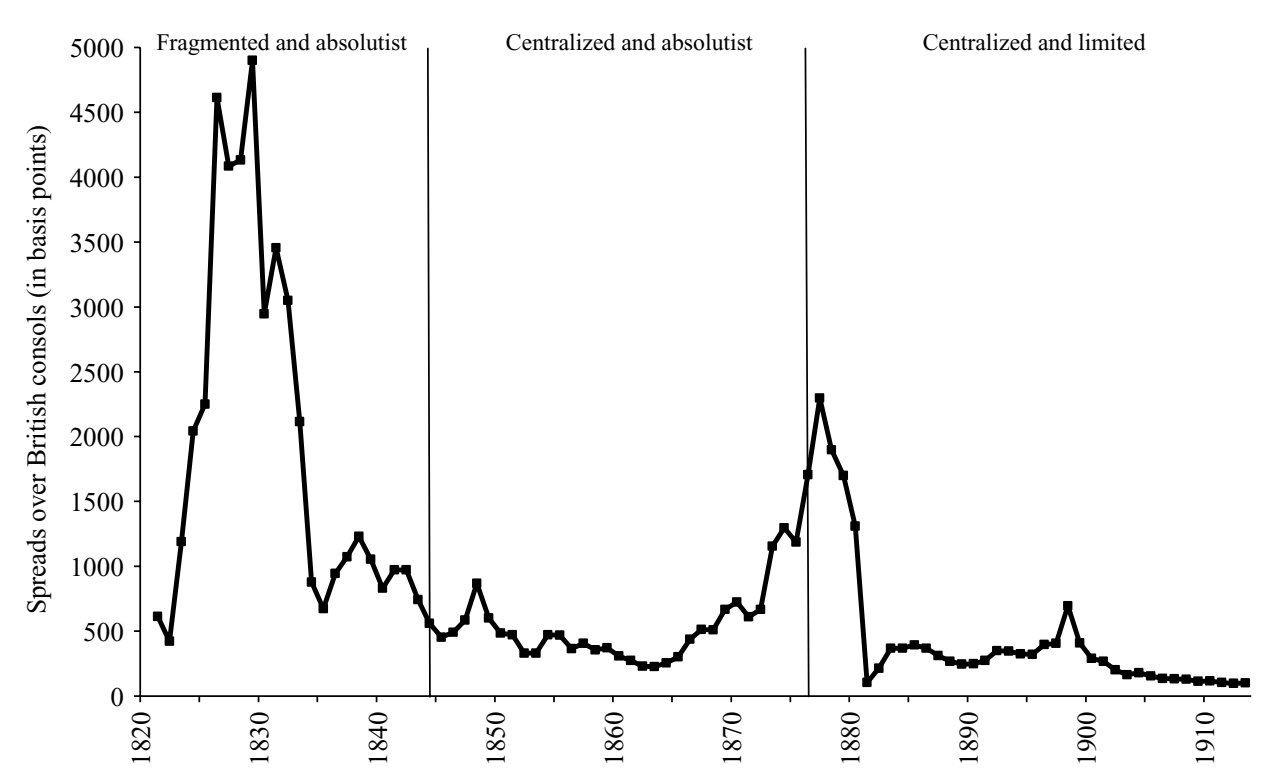

Figure 3. Yield spreads, Spain, I82I-I9I3

Sources: See Appendix I.

in 1806 had roughly doubled the size of the Dutch tax base and Europe was politically stable. Dincecco (2009b) argues that rapid growth in Dutch deficits from I8I5 onwards reflected the reckless policies that Willem pursued. Yield spreads rose with the Belgian Revolt of 1830 and subsequent War of Independence (1830-1833). ${ }^{14}$ In hope of reclaiming Belgium, Willem continued to spend great sums on the military. During the I830s, Dutch spreads remained around I50 basis points higher than spreads under the constitutional 'July' regime in France. When Dutch fiscal troubles finally became public in I839, parliament vetoed the upcoming decadal budget and Willem abdicated his throne. As parliament's power of the purse increased over the I840s, spreads fell to Ioo basis points. After the Revolutions of I848, which saw the establishment of a stable centralized and limited regime, spreads typically remained less than IOo basis points through the start of World War I.

To supplement the French and Dutch cases, it is useful to examine the rest of the data. Figure 3, which plots yield spreads between Spanish long-term government bonds and British consols from 1820 to 1913, indicates that spreads fell by roughly 500 basis points after fiscal centralization in 1844 . The establishment of a stable form of limited government in 1876 also led to a sizeable reduction in Spanish spreads.

${ }^{14}$ The loss of tax revenues from southern provinces also aggravated Dutch finances. See

Fritschy, t'Hart and Horlings (200I). 


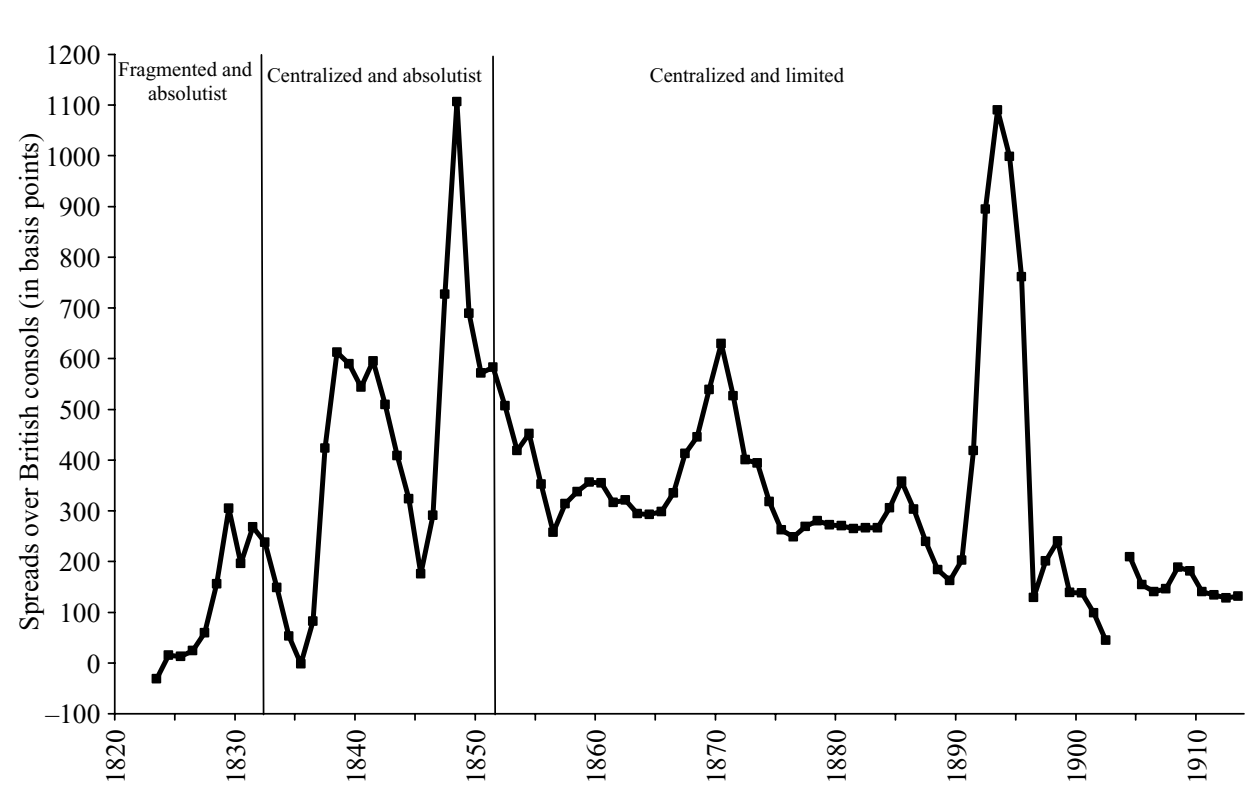

Figure 4. Yield spreads, Portugal, I823-1913

Sources: See Appendix I.

Figure 4, which plots yield spreads between Portuguese long-term government bonds and British consols from I823 to I9I3, indicates that spreads were higher after fiscal centralization in 1832 than beforehand. The period from I82I to I85I, however, was one of civil war as well as colonial conflict. ${ }^{15}$ Portuguese spreads fell with the establishment of a stable form of limited government in I85I. Moreover, during much of the I850s and I860s, spreads in Portugal were typically IOO to 200 basis points lower than those of Spain, its absolutist counterpart on the Iberian Peninsula.

Figure 5, which plots yield spreads between Prussian long-term government bonds and British consols from I8I5 to I9I3, indicates that spreads rose in the decades after the establishment of limited government in Prussia in I848. Infrequent observations from I 842 to I869, however, may misrepresent Prussian yield trends. Since weekly or monthly data was not available, I used annual data (taken from the last day of trading each year) from Homer and Sylla (I99I). ${ }^{16}$ Military conflicts also played a role. Though it did not participate in any major wars from I8I5 to 1847 , Prussia entered four such conflicts from 1848 to $187 \mathrm{I} .{ }^{17}$

is See Birmingham (1993), Mata and Valerio (2002) and Clodfelter (2002).

${ }^{16}$ For additional details, see Appendix I.

17 These were the first and second Schleswig-Holstein Wars (I848-9, I864), the

Austro-Prussian War (I866) and the Franco-Prussian War (I870-I). Also see Appendix 2. 


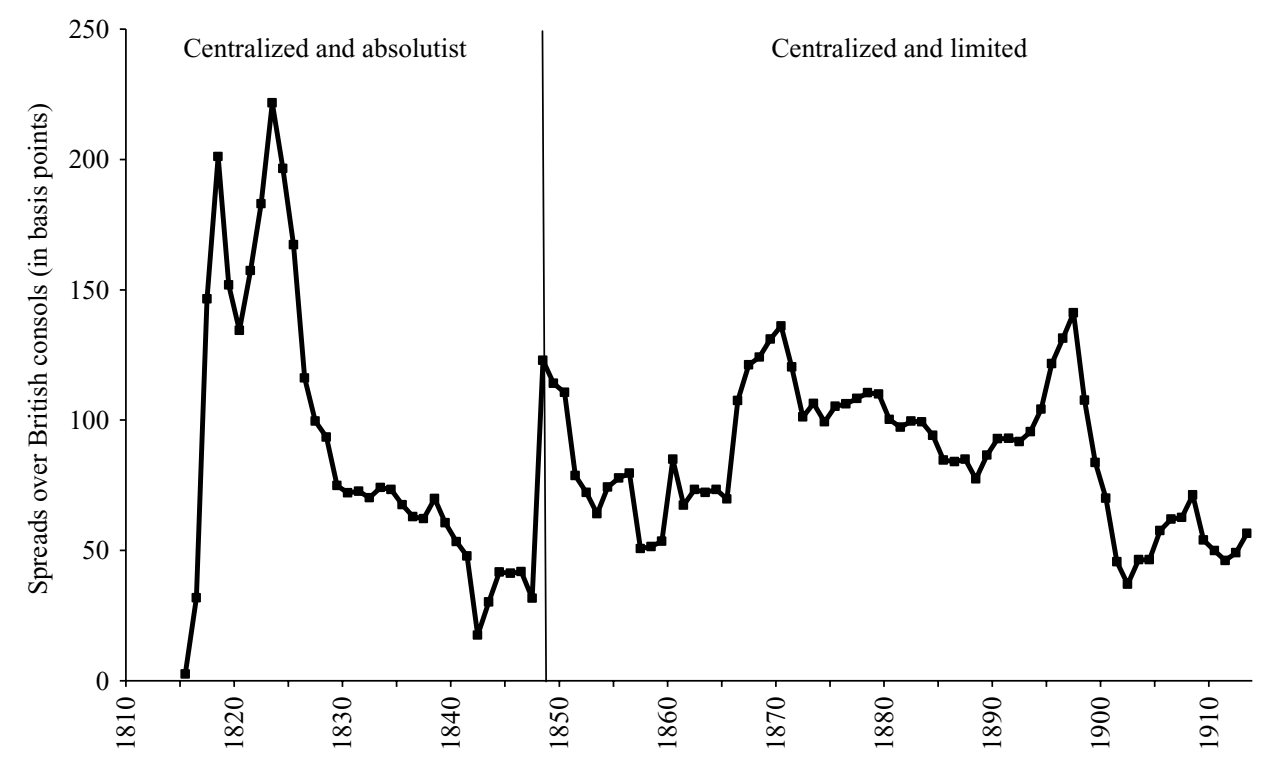

Figure 5. Yield spreads, Prussia, I815-I9I3

Sources: See Appendix I.

Indeed, qualitative accounts suggest a positive relationship between limited government and public finances in Prussia. According to Ferguson (1998), Rothschild lenders urged King Frederick William II (I786-97) to implement constitutional reforms as a credible way to improve sovereign credit risk. Tilly (1966, 1967), moreover, argues that the constitutional reforms of 1848 strengthened the ability of the Prussian parliament to follow sound fiscal policies. Finally, the quantitative analysis by Dincecco (2009a) finds that limited government in Prussia led to a significant increase in percapita tax revenues. ${ }^{18}$

Though the evidence presented so far suggests that political transformations had important effects on sovereign credit risk, it is not definitive. Figure 6, which plots yield spreads for group 2 countries from 1820 to I9I3, highlights the importance of controls for factors besides political regime. By the I870s, for instance, it is difficult to distinguish between deficit ratios associated with the absolutist regime in Denmark and those associated with limited regimes elsewhere. To account for the effects of violent conflict,

${ }^{18}$ Southern Germany polities like Bavaria adopted constitutions at the start of the I80os. To compare Bavarian and Prussian yield spreads from I8I5 to I848, I used annual data provided by Homer and Sylla (I99I). The results indicated that spreads under the limited government regime in Bavaria were consistently lower than spreads under the absolutist one in Prussia. 


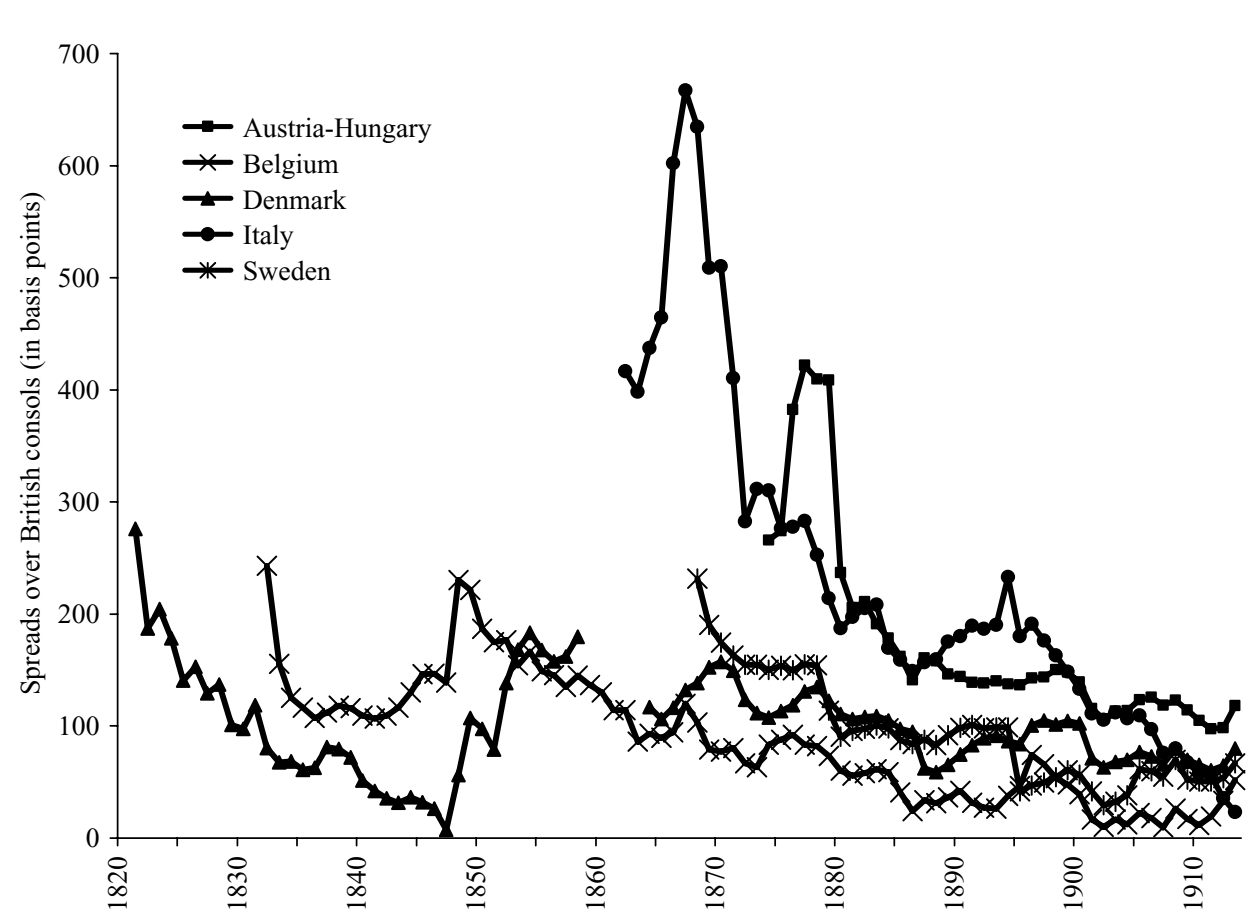

Figure 6. Yield spreads, group 2 countries, $1820-1913$

Sources: See Appendix I.

economic growth, fiscal and monetary policy, and other elements, I now turn to a more rigorous quantitative analysis.

\section{Statistical tests}

\section{I. Panel regressions}

Estimations of panel data increase informative content by combining variations across time and country. I followed Beck and Katz (1995) and employed ordinary least squares with 'panel-corrected' standard errors (PCSE), which corrects for contemporaneously correlated errors and panel heteroskedasticity. To control for serial correlation, I included a common ARI term. ${ }^{19}$

The basic fixed effects specification is:

Spread $_{i t}=\beta_{\mathrm{o}}+\beta_{\mathrm{I}} \mathrm{CA} \mathrm{regime}_{i t}+\beta_{2}$ FL regime $_{i t}+\beta_{3}$ CL regime $_{i t}+\gamma \mathrm{X}_{i t}+\mu_{i}+\varepsilon_{i t}$

19 Beck and Katz (1995) also show that use of a common $\rho$ to control for serial correlation is superior to that of unit-specific ones. 
where $\operatorname{Spread}_{i t}$ is the yield spread with British consols in basis points for country $i$ in year $t, \mathrm{X}_{i t}$ is a vector of control variables to be described, $\mu_{i}$ represent country-specific fixed effects, and $\varepsilon_{i t}$ is the disturbance term. ${ }^{20}$ I used dummy variables for centralized and absolutist (CA), fragmented and limited (FL), and centralized and limited (CL) regimes relative to fragmented and absolutist ones as a clear and simple method to measure the effect of political arrangements on sovereign credit risk. ${ }^{2 I}$

Hoffman and Rosenthal (1997) claim that early modern monarchs valued warfare above all else. For the I800s, Ferguson (2006) argues that political events were more important to investors than economic ones since there was a greater amount of regular information available about them. Sussman and Yafeh $(2000,2006)$ also find that financial markets responded quickly to wars and civil unrest. One might expect that the total effect of warfare on sovereign credit risk was negative because it decreased tax revenues and increased public expenditures. Over the long run, however, Kindleberger (1984), Tilly (1990), Hoffman and Norberg (1994), Epstein (2000), O'Brien (200I), Rosenthal and Wong (2007) and others argue that military competition fostered financial innovations that allowed sovereigns to reduce credit risk. Whether a country won or lost a conflict also influenced public finances. To evaluate the impact of warfare on yield spreads, I included a dummy variable that identified each year from I750 to I9I3 in which sample countries were engaged in military conflicts in Western or Eastern Europe according to Clodfelter (2002). Appendix 2 documents the details.

Though debt figures would also be useful to measure the effects of warfare on public finances, continuous series were not available prior to the I870s (see Ferguson 2006). One unique source of data that exists from the I700s onwards is budgetary figures as assembled by Dincecco (2009b). To scale estimates across time, Ferguson and Schularick (2006) claim that sophisticated analyses of government finances typically employed public revenues. Cain and Hopkins (1994) also argue that budget deficitto-revenue ratios were the statistic most preferred by investors to evaluate macroeconomic policies. ${ }^{22}$ In accordance with the 'gentlemanly capitalists' of London, I used this variable as a measure of fiscal prudence. Table 5

${ }^{20}$ Britain went off the gold standard from I797 to I82 I and France adhered to a bimetallic standard for much of the I80os. To avoid risk elements that reflected exchange rate regimes, I also tested alternative specifications that used natural logarithms of average annual yields as the dependent variable. The results were unaffected.

${ }^{21}$ I did not use yearly fixed effects because the number of annual observations for group I countries typically exceeded I20. Both Greene (2000) and Wooldridge (2003) argue that the large cost in terms of lost degrees of freedom makes it difficult to justify yearly fixed effects in such cases. Instead, I implemented time controls that captured widespread shocks such as systematic risk and warfare. However, the findings were also robust to the inclusion of annual time dummies.

${ }^{22}$ Also see Davis and Huttenback (1986) and Flandreau and Zumer (2004). 
Table 5. Summary statistics of non-binary control variables

\begin{tabular}{lcccr}
\hline \hline & Mean & St. Dev. & \multicolumn{1}{c}{ Min } & \multicolumn{1}{c}{ Max } \\
\hline Budget deficit-to-revenue ratios & 0.19 & 0.32 & -0.89 & 2.93 \\
Urbanization rate & 0.15 & 0.08 & 0.04 & 0.43 \\
Average annual yield spreads & 226 & I85 & -IOI & 948 \\
\hline \hline
\end{tabular}

Sources: See Appendix 2.

indicates that the average deficit ratio was 0.19. The lowest deficit ratio was -0.89 for Spain in 1803 and the largest was 2.93 for France in 1790.

There also exists systematic information for debt default, an extreme reaction to fiscal crisis that caused widespread damage to the financial sector as well as the economy as a whole. ${ }^{23}$ Indeed, early modern executives often resorted to default as a way to handle large debt burdens accumulated during wars. $^{24}$ To measure this effect, I introduced a dummy variable that identified all years of partial or full defaults on publicly held debts from I750 to I9I3 according to Reinhart, Rogoff and Savastano (2003) and Dincecco (2009b). Appendix 2 provides the details.

Since internal conflict caused disruptions that increased sovereign credit risk, we must consider the impact of domestic turmoil as well. To measure this effect, I included a dummy variable that identified all civil wars, coups and revolutions that occurred within sample countries from I750 to I913. Appendix 2 describes the details.

One might also suppose that economic growth increased tax bases and enabled sovereign governments to repay debts. Since reliable GDP figures are difficult to come by before 1820 , many studies of the late nineteenth century employ measures of foreign trade as approximates of national output (e.g. Mauro, Sussman and Yafeh 2002; Obstfeld and Taylor 2003; Ferguson and Schularick 2006). However, systematic trade deficit and export series from the I700s onwards were not available. Hohenberg and Lees (1985), Bairoch (1988) and Acemoglu, Johnson and Robinson (2002, 2005) argue that there was a close relationship between urbanization rates and income growth. To proxy for per-capita GDP, I constructed a yearly variable that calculated urban populations as fractions of total populations for each country. Appendix 2 describes the details. ${ }^{25}$ Controls for national income also help account for different rates of technological innovation and adoption across countries (see Mokyr 1998, 1999). Table 5 indicates that on average urban populations comprised 17 percent of total populations. The lowest

${ }^{23}$ Currency debasement was another form of government 'misbehavior', but systematic data across sample countries were not found.

${ }^{24}$ For example, two of the three defaults that Sargent and Velde (1995) describe for France during the century prior to 1789 involved military conflicts: the 1715 episode after the War of Spanish Succession and the I759 one during the Seven Years' War.

${ }^{25}$ I used Maddison's (2003) per-capita GDP figures as a robustness check. 
urbanization rates were 4 percent for Prussia during the second half of the I 700 s and the largest were over 40 percent for the Netherlands at the start of the I900s.

Bordo and Rockoff (1996) and Obstfeld and Taylor (2003) claim that adherence to the classic gold standard was a valuable signal of financial integrity. To measure the effect of monetary policy, I included a dummy variable that took a value of one for each year that a country was on gold from the I870s to the start of World War I. Since polities such as Spain 'shadowed' the gold standard while never making an official commitment, coding was at times subjective. I relied on Meissner's (2005) dates at which a currency became de facto and de jure convertible into gold. Appendix 2 documents the details.

Lastly, to control for systematic risk across European asset markets, I computed an average yield spread in basis points for all available sample countries over the 'safe' British consol each year in the spirit of Bordo and Rockoff (1996), Obstfeld and Taylor (2003) and Ferguson and Schularick (2006). Use of a GDP-weighted benchmark spread or a CAPM-style variable that interacted country fixed effects and country-specific risk premiums did not significantly alter any of the results. ${ }^{26}$ Table 5 indicates that systematic risk averaged 226 basis points. Fueled by the Dutch Republic, the lowest 'world' spreads occurred in the I780s and were negative. The largest (948 basis points) occurred in I8I I at the height of the Napoleonic Wars.

The econometric set-up assumes that it is possible to disentangle political regimes from factors such as violent conflicts and economic fundamentals. Since political arrangements influenced all of these characteristics, coefficients on the control variables rather than those on the regime ones themselves may capture some of the positive effects of institutional reforms. Hence, regime coefficients are likely to underestimate the total impact of political arrangements on sovereign credit risk.

\subsection{Structural break tests}

Structural break tests, which assume no a priori knowledge of major turning points in the revenue series for group I countries, supplement the PCSE regression analysis by letting the data 'speak' for themselves. ${ }^{27} \mathrm{I}$ use the methodology proposed by Bai and Perron (2003) that identifies multiple structural changes in means while allowing for serial correlation. It thus improves upon the 'moving windows' technique that relies upon sequential single structural change methods.

${ }^{26}$ Data were not available to produce a debt-weighted average spread.

${ }^{27}$ Historical applications include Willard, Guinnane and Rosen (1996), Brown and

Burdekin (2000), Sussman and Yafeh (2000), Mauro, Sussman and Yafeh (2002) and

Dincecco (2009a, 2009b). 
A program created for the Regression Analysis of Time Series (RATS) software performs the Bai-Perron procedure, which estimates the following regression for each sample country:

$$
\text { Spread }_{t}=\beta_{\circ}+\Sigma_{l=\mathrm{I}, \ldots, L} \beta_{l} \text { Spread }_{t-l}+\varepsilon_{t}
$$

where $\operatorname{Spread}_{i t}$ is the yield spread with British consols in basis points in year $t, \beta_{o}$ and $\beta_{\mathrm{I}}$ through $\beta_{L}$ are parameters to be estimated, and $\varepsilon_{\mathrm{t}}$ is the disturbance term. I allowed up to five significant yearly lags of the dependent variable $(L=5)$. The RATS routine, which uses a dynamic programming algorithm to evaluate which final partitioning of the time series data achieves a global minimization of the overall sum of squared residuals, returns the optimal set of break points.

The RATS procedure calls for the selection of a maximum number of 'best' turning points in the time series for each country subject to a minimum number of observations between data segments. As Willard, Guinnane and Rosen (I996) point out, there is always a trade-off in determining parameter values. A minimum space of two observations eliminates the chance of confounding the effects of different events but ends up analyzing blips (false positives that characterize certain events as 'long-lasting' that really were not) rather than turning points. Longer periods of analysis, however, increase the likelihood of missing important shifts (false negatives).

There are also data limitations to consider. Though gaps from I789 to I8I5 in the French and Dutch yield series prevented the identification of turning points associated with fiscal centralization, it was still possible to capture post-I8I 5 breaks for limited government. The same held for Portugal, where the yield series began just before centralization, and Prussia, where it began just afterwards. After some experimentation, I selected the best three breaks with at least 15 observations (i.e. I5 years) per segment. ${ }^{28} \mathrm{~A}$ long continuous run of data set England apart from other group I countries. Though the English series began after the establishment of a centralized and limited regime, it remains useful to study the relationship between military conflicts, political regimes and credit risk.

\section{Statistical evidence}

Table 6, which shows the results of the panel regressions, indicates that fragmented and absolutist regimes displayed significantly higher levels of sovereign credit risk than the other regime types. These findings held for group I countries only (column I) and when group 2 countries were included (column 2). Ceteris paribus, the move to a centralized and absolutist regime

${ }^{28}$ I also set the maximum number of breaks to 2, 4 or 5 and the minimum number of observations to IO or 20 . The findings were generally robust to such changes in parameter values. 
Table 6. Regression results for political regimes and sovereign credit risk

\begin{tabular}{|c|c|c|}
\hline & $\begin{array}{c}\text { (I) } \\
\text { Group I only }\end{array}$ & $\begin{array}{l}\text { (2) } \\
\text { Groups I and } 2\end{array}$ \\
\hline Centralized and absolutist regimes & $\begin{array}{c}-\mathrm{I} 47.99^{* * *} \\
(2.90)\end{array}$ & $\begin{array}{c}- \text { I53.I } 2^{* * *} \\
(5.74)\end{array}$ \\
\hline Fragmented and limited regimes & $\begin{array}{c}-383.46^{* * *} \\
(7.48)\end{array}$ & $\begin{array}{c}-384.74^{* * *} \\
(\mathrm{I} 4.49)\end{array}$ \\
\hline Centralized and limited regimes & $\begin{array}{c}-192.70^{* * *} \\
(3.09)\end{array}$ & $\begin{array}{c}-\mathrm{I} 86.05^{* * *} \\
(5.83)\end{array}$ \\
\hline Military conflicts & $\begin{array}{l}21.06^{* *} \\
(2.39)\end{array}$ & $\begin{array}{l}21.07^{* * *} \\
(5.24)\end{array}$ \\
\hline Deficit-to-revenue ratios & $\begin{array}{l}34.45^{*} \\
(\mathrm{I} .7 \mathrm{I})\end{array}$ & $\begin{array}{l}30.8 \mathrm{I}^{* * * *} \\
(4.4 \mathrm{I})\end{array}$ \\
\hline Defaults & $\begin{array}{l}61.76 \\
(1.27)\end{array}$ & $\begin{array}{l}40.89^{*} \\
(1.89)\end{array}$ \\
\hline Civil wars, coups, revolutions & $\begin{array}{c}50.66^{* *} \\
(2.32)\end{array}$ & $\begin{array}{l}44.62^{* * *} \\
(4.19)\end{array}$ \\
\hline Urbanization rate & $\begin{array}{c}-3 \mathrm{I} 7.5 \mathrm{I} \\
(0.98)\end{array}$ & $\begin{array}{r}-14 \mathrm{I} .32 \\
(0.94)\end{array}$ \\
\hline Gold standard & $\begin{array}{l}23.98 \\
(0.98)\end{array}$ & $\begin{array}{r}-16.26 \\
(I .38)\end{array}$ \\
\hline Average yield spread & $\begin{array}{l}22.43^{* * *} \\
(\text { I I.69) }\end{array}$ & $\begin{array}{l}26.19^{* * *} \\
(21.30)\end{array}$ \\
\hline Netherlands & $\begin{array}{l}71.78 \\
(\mathrm{I} .47)\end{array}$ & $\begin{array}{c}46.79^{* *} \\
(2.2 \mathrm{I})\end{array}$ \\
\hline Prussia & $\begin{array}{c}\text { I.95 } \\
(0.09)\end{array}$ & $\begin{array}{c}-0.44 \\
(0.00)\end{array}$ \\
\hline Spain & $\begin{array}{l}442.10^{* * *} \\
(6.90)\end{array}$ & $\begin{array}{l}432.54^{* * *} \\
(12.34)\end{array}$ \\
\hline Austria-Hungary & & $\begin{array}{l}\text { II } 0.46^{* * *} \\
\quad(6.7 \mathrm{I})\end{array}$ \\
\hline Belgium & & $\begin{array}{l}34.4 \mathrm{I}^{* * *} \\
(3.08)\end{array}$ \\
\hline Denmark & & $\begin{array}{l}\text { I2.88 } \\
(0.85)\end{array}$ \\
\hline Italy & & $\begin{array}{l}\mathrm{I} 72.20^{* * *} \\
(\mathrm{I} 2.08)\end{array}$ \\
\hline Portugal & & $\begin{array}{c}244.15^{* * *} \\
\quad(6.53)\end{array}$ \\
\hline Sweden & & $\begin{array}{c}4 \mathrm{I} .72^{* *} \\
(2.12)\end{array}$ \\
\hline Constant & $\begin{array}{c}245.68^{* * *} \\
(6.90)\end{array}$ & $\begin{array}{l}222.89^{* * *} \\
(\mathrm{I} 2.76)\end{array}$ \\
\hline $\begin{array}{l}\text { Observations } \\
\mathrm{R}^{2}\end{array}$ & 346 & 652 \\
\hline Wald $\chi^{2}$ & $\begin{array}{l}0.400 \\
621.79\end{array}$ & $\begin{array}{r}0.357 \\
3850.36\end{array}$ \\
\hline
\end{tabular}

Sources: See text.

${ }^{*}$ Significant at Io percent level, ${ }^{* *}$ Significant at 5 percent level, ${ }^{* * *}$ Significant at I percent level.

Notes: The dependent variable is the annual yield spread with the British consol in basis points. The estimation technique is OLS with panel-corrected standard errors (PCSE). A common ARI term was added to correct for serial correlation. Z-statistics in absolute values are in parentheses. Group I: France, the Netherlands, Prussia and Spain. Group 2: Austria-Hungary, Belgium, Denmark, Italy, Portugal and Sweden. For details about the regression variables, see Appendix 2. 
decreased yield spreads by 148 to I53 basis points. This result suggests that the positive impact of new revenues outweighed the negative impact of executive consolidation of fiscal powers. The move to a centralized and limited regime decreased yield spreads by 186 to 193 basis points and the move to the fragmented and limited one by 383 to 385 basis points. ${ }^{29}$ The findings were also robust to checks that used alternative regime classifications. ${ }^{30}$

As expected, warfare had a significant negative impact on sovereign credit risk. Common shocks to European asset markets (e.g. large-scale military conflicts) were also associated with a significant increase in yield spreads. Domestic turmoil (civil wars, coups and revolutions) significantly worsened credit risk as well. Budget deficits and defaults also had negative effects, though to a lesser extent. Urbanization rates and gold standard adherence, meanwhile, had negligible impacts. ${ }^{3 \mathrm{I}}$ Finally, Spain, AustriaHungary, Belgium, Italy, Portugal and Sweden all had notably larger spreads than did France.

Table 7, which displays the results of the structural break tests, reveals close relationships between major turning points in the yield spread series and political transformations that enhanced public finances. It also highlights the link between those innovations and military competition and conflicts. In the Netherlands, the best breaks came with the start of the Belgian War of Independence (1830), near limited government (1850), and with an unidentified event (I885). Limited government, which occurred during the Year of Revolutions in 1848 , led to a significant decrease in spreads (29 percent).

In France, the first turning point occurred with the July Revolution (I830) and the establishment of the short-lived constitutional regime (I830-47) that followed. Limited government led to a significant (73 percent) decrease in yield spreads. A second break coincided with the coup d'état and subsequent establishment of an authoritarian regime by Napoleon III at the start of the I850s. As expected, it was associated with a significant (I63 percent) increase in spreads. The final break (I87I) came with the establishment of limited government (I870) and the Franco-Prussian War (I870-7I). France's loss to Prussia appears to have offset the positive effects of limited government over the short term. Figure I, however, indicates that French spreads fell steadily from 1872 onwards. By the I880s, they resembled those under the constitutional 'July' regime from 50 years before.

${ }^{29}$ Recall that the Dutch Republic, characterized by 16 observations, was the sole case among sample countries of a fragmented and limited regime. Hence, the magnitude of this result should be interpreted with care.

30 Parliaments may have required time to see how well executives would honor commitments. The first alternative allowed for uncertainty over how long new limited regimes would last by lagging their start dates by 5 or Io years. The second alternative classified the 'borderline' political regime in France (1830-47) as centralized and limited rather than as centralized and absolutist.

${ }^{31}$ Use of per-capita GDP figures rather than urbanization rates did not significantly affect the findings. 
Table 7. Major breaks in yield spread series

\begin{tabular}{|c|c|c|c|}
\hline & Year & Percent change & Event \\
\hline \multirow[t]{3}{*}{$\begin{array}{l}\text { England } \\
\quad(1750-1913)\end{array}$} & I775 & $\begin{array}{l}27.5 \mathrm{I}^{* * *} \\
(5.47)\end{array}$ & $\begin{array}{l}\text { Start of War of American } \\
\text { Independence }\left(1775^{-83}\right)\end{array}$ \\
\hline & I798 & $\begin{array}{l}\text { II.36** } \\
(2.37)\end{array}$ & Start of Napoleonic Wars (I799-I8I5) \\
\hline & I8I5 & $\begin{aligned}- & -18.19^{* * *} \\
& (5.45)\end{aligned}$ & End of Napoleonic Wars (I799-I8I5) \\
\hline \multirow[t]{3}{*}{$\begin{array}{l}\text { France } \\
\qquad(1815-1913)\end{array}$} & I829 & $\begin{array}{l}-73.73^{* * *} \\
(5.75)\end{array}$ & $\begin{array}{l}\text { July Revolution (I830) / Short-lived } \\
\text { constitutional regime (I830-47) }\end{array}$ \\
\hline & I847 & $\begin{array}{l}163.53^{* * *} \\
(5.05)\end{array}$ & $\begin{array}{l}\text { Year of Revolutions (I848) / Coup by } \\
\text { Napoleon III (I85I) }\end{array}$ \\
\hline & I87I & $\begin{array}{c}4.1 \mathrm{I} \\
(0.78)\end{array}$ & $\begin{array}{l}\text { Limited government (I870) / } \\
\text { Franco-Prussian War (I870-I) }\end{array}$ \\
\hline \multirow[t]{3}{*}{$\begin{array}{l}\text { Netherlands } \\
\quad(1815-1913)\end{array}$} & 1830 & $\begin{array}{l}33 \cdot 34^{* * *} \\
(2.63)\end{array}$ & $\begin{array}{l}\text { Belgian Revolt (I830) / Belgian War of } \\
\text { Independence (I830-3) }\end{array}$ \\
\hline & I 848 & $\begin{array}{l}-29.16^{* * *} \\
(3.05)\end{array}$ & $\begin{array}{l}\text { Limited government (I848) / Year of } \\
\text { Revolutions (I848) }\end{array}$ \\
\hline & I885 & $\begin{array}{l}-60.48^{* * *} \\
(7.93)\end{array}$ & Unidentified event \\
\hline \multirow[t]{3}{*}{$\begin{array}{l}\text { Portugal } \\
\qquad(1823-1902)\end{array}$} & I 848 & $\begin{array}{l}26.54 \\
(\text { I.I9) }\end{array}$ & $\begin{array}{l}\text { Limited government (I85I) / Colonial } \\
\text { Wars in Guinea (I840s) }\end{array}$ \\
\hline & I863 & $\begin{array}{r}-\mathrm{I} 8.32 \\
\quad(\mathrm{I} .34)\end{array}$ & Unidentified event \\
\hline & I887 & $\begin{array}{l}31.64 \\
(1.03)\end{array}$ & Banking crisis (I890s) \\
\hline \multirow[t]{3}{*}{$\begin{array}{l}\text { Prussia } \\
\qquad(1815-1913)\end{array}$} & I829 & $\begin{array}{l}-5 \mathrm{I} .58^{* * *} \\
(4.28)\end{array}$ & Ist Zollverein customs union (I834) \\
\hline & I847 & $\begin{array}{l}56.44^{* * *} \\
(5 \cdot 39)\end{array}$ & $\begin{array}{l}\text { Limited government (I848) / Ist } \\
\text { Schleswig-Holstein War (I848-9) }\end{array}$ \\
\hline & I 866 & $\begin{array}{l}20.5 \mathrm{I}^{* * *} \\
(3.69)\end{array}$ & Austro-Prussian War (1866) \\
\hline \multirow[t]{3}{*}{$\begin{array}{l}\text { Spain } \\
\qquad(\mathrm{I} 82 \mathrm{I}-\mathrm{I} 9 \mathrm{I} 3)\end{array}$} & I835 & $\begin{array}{l}-69.33^{* * *} \\
(4.63)\end{array}$ & End of Ist Carlist War (I833-9) \\
\hline & I864 & $\begin{array}{l}\mathrm{I} 49.54^{* * *} \\
\quad(3.50)\end{array}$ & Start of Naval War with Peru (I865-6) \\
\hline & I879 & $\begin{array}{l}-5 \mathrm{I} .70^{* *} \\
(2.50)\end{array}$ & $\begin{array}{l}\text { Limited government (I876) / End of } \\
\text { 3rd Carlist War (I872-6) }\end{array}$ \\
\hline
\end{tabular}

Sources: See text.

${ }^{*}$ Significant at Io percent level, ${ }^{* *}$ Significant at 5 percent level, ${ }^{* *}$ Significant at I percent level.

Notes: The first column lists the relevant sample countries. The second column displays the years for the best three structural breaks over the years shown for each polity as determined by the algorithm described in the text. The third column reports the percentage change in yield spreads over the fifteen years following the break in question as compared to the fifteen years that preceded it. T-statistics in absolute values are in parentheses. The final column offers brief 'explanations' for the turning points, which are elaborated upon in the text. For England, yields on British consols rather than spreads were tested. 
In Portugal, the turning point that occurred in I 848 coincided with the establishment of limited government in I85I as well as the I840s colonial wars in Guinea. By the mid I 850s, Portuguese spreads had fallen by over 300 basis points. Other Portuguese breaks were associated with an unidentified event (1863) and the I89os banking crisis. In Prussia, we observe turning points near the first Zollverein customs agreement in I834, near the establishment of a centralized and limited regime in I848 and the first Schleswig-Holstein War (I848-9), and with the Austro-Prussian War (I866). Section 4 examines why limited government in Prussia did not result in a spread reduction.

The best three turning points for Spain occurred at the end of the first Carlist Civil War (I833-9), near the start of the Naval War against Peru (I864), and near limited government (I879). Limited government, established at the end of the third Carlist Civil War (I872-6), was associated with a large decrease in yield spreads (52 percent). Curiously, fiscal centralization, which occurred in I844 during a decade of reforms, was not included as one of the top Spanish breaks. Figure 4, however, shows that yield spreads fell by roughly 500 basis points in the decade or so that followed this political change.

Turning points in the English yield series, which began after the establishment of a centralized and limited regime, further highlight the role of military conflicts. The top three breaks came at the start of War of American Independence (1775) and near the start (1798) and finish (1815) of the Napoleonic Wars. In each case, we observe a significant increase in consol yields at the conflict's outbreak (I775, I798) and a significant decrease at war's end (1815).

\section{Conclusion}

This article examines the relationship between political regimes and sovereign credit risk in Europe from I750 to I913. Panel regressions indicate that centralized and/or limited regimes were associated with significant creditworthiness improvements relative to fragmented and absolutist ones. Structural break tests that assume no a priori knowledge of possible turning points in the yield series support these conclusions.

Historical analysis reveals general patterns in the evolution of political regimes and public finances. Prior to the I80os, the most urgent problem facing most polities was fiscal fragmentation. Since Old Regime monarchs were already 'constrained' by local tax authorities, it was not until after centralization that national parliaments became 'the' mechanism by which to hold crowns accountable.

We lose sight of this point when studying English financial history, which was exceptional. By managing to avoid the problems of severe fragmentation that hampered Continental countries for so long, England was in a better 
position for development. Our key lesson from history, then, is simple but powerful. Today's emerging economies must try to adopt fiscal structures that not only limit the power of executives to behave recklessly, but that also lend enough authority to central governments to collect sufficient tax funds.

\section{Acknowledgements}

This article is a revised version of the second chapter of my $\mathrm{PhD}$ dissertation (UCLA, 2006). I would like to offer my sincere gratitude to my graduate advisor, Jean-Laurent Rosenthal, as well as to Naomi Lamoreaux. I would also like to thank Kimberly Crawford, Giovanni Federico, Wantje Fritschy, Knick Harley, Philip Hoffman, Joost Jonker, Robert Margo, Marjolein t'Hart, Mark Weidenmier, Jaime Reis and Jan Luiten van Zanden for valuable suggestions and/or help with the construction of the data set. Albrecht Ritschl and two anonymous referees provided useful comments, as did seminar participants at the EHA Annual Meeting (2006), the Collegio Carlo Alberto, the Universidad Carlos III, IMT Lucca, UCLA, and the All-UC Group in Economic History Workshop (2005). Finally, I would like to thank IMT Lucca, the Institute for Humane Studies, and UCLA for financial support.

\section{References}

Acemoglu, D., Johnson, S. and Robinson, J. (2002). Reversal of fortune: geography and development in the making of the modern world income distribution. Quarterly fournal of Economics II7, pp. I23I-94.

ACEMOGLu, D., JoHnson, S. and Robinson, J. (2005). The rise of Europe: Atlantic trade, institutional change, and economic growth. American Economic Review 94, pp. 546-79.

BAI, J. and PERRON, P. (2003). Computation and analysis of multiple structural-change models. Fournal of Applied Econometrics 18, pp. I-22.

BaIRoch, P. (1988). Cities and Economic Development: From the Dawn of History to the Present. Chicago: University of Chicago Press.

BECK, N. and KATZ, J. (1995). What to do (and not to do) with time-series cross-section data. American Political Science Review 89, pp. 634-47.

Birmingham, D. (1993). A Concise History of Portugal. Cambridge: Cambridge University Press.

Bonney, R. (1995). Economic Systems and State Finance. Oxford: Oxford University Press.

Bonney, R. (1999). The Rise of the Fiscal State in Europe, I200-I815. Oxford: Oxford University Press.

BORDO, M. and CoRTÉs-CONDE, R. (eds.) (200I). Transferring Wealth and Power from the Old to the New World: Monetary and Fiscal Institutions in the Seventeenth through the Nineteenth Centuries. Cambridge: Cambridge University Press. 
Bordo, M. and RockofF, H. (I996). The gold standard as a good housekeeping seal of approval. Fournal of Economic History 56, pp. 389-428.

Brewer, J. (1989). The Sinews of Power: War, Money, and the English State, I688-I783. London: Unwin Hyman.

BROWN, W. and BURDEKIN, R. (2000). Turning points in the US Civil War: a British perspective. Fournal of Economic History 6o, pp. 216-3I.

BRowN, W., BURDEKIN, R. and WEIDENMIER, M. (2006). Volatility in an era of reduced uncertainty: lessons from Pax Brittanica. Fournal of Financial Economics 79, 693-707.

CAIN, P. J. and HopkINS, A. G. (I994). British Imperialism. London: Longman.

ClARK, G. (1996). The political foundations of modern economic growth: England, I 540-1800. Fournal of Interdisciplinary History 26, pp. 563-88.

Clodfelter, M. (2002). Warfare and Armed Conflicts: A Statistical Reference to Casualty and Other Figures, 1500-2000, 2nd edn. Jefferson: McFarland.

Cust, R. (1987). The Forced Loan and English Politics, I626-I628. Oxford: Clarendon Press.

Davis, L. and HutTenback, R. (1986). Mammon and the Pursuit of Empire: The Political Economy of British Imperialism. Cambridge: Cambridge University Press.

DE VRIES, J. (1984). European Urbanization, 1500-I800. Cambridge, MA: Harvard University Press.

Dickson, P. (1967). The Financial Revolution in England: A Study in the Development of Public Credit, I688-I756. New York: St Martin's Press.

DinCECCO, M. (2009a). Fiscal centralization, limited government, and public revenues in Europe, I650-I913. Fournal of Economic History 69, pp. 48-103.

DincECCO, M. (2009b). The political economy of fiscal prudence in historical perspective. Forthcoming, Economics $\mathcal{E}$ Politics.

The Economist.

EPSTEIN, S. R. (2000). Freedom and Growth: Markets and States in Europe, I300-I750. London: Routledge.

Encyclopedia Britannica 2007.

FERGuson, N. (I998). The House of Rothschild: Money's Prophet, I798-I848. New York: Penguin.

FERGuSON, N. (2006). Political risk and the international bond market between the 1848 revolution and the outbreak of the First World War. Economic History Review 59, pp. 70-II2.

FERGuson, N. and SCHULARICK, M. (2006). The empire effect: determinants of country risk in the first age of globalization, I880-I913. Fournal of Economic History 66, pp. 283-3I2.

Flandreau, M. and ZuMER, F. (2004). The Making of Global Finance, I880-19I3. Paris: OECD.

FREY, B. and KUCHER, M. (2000). History as reflected in capital markets: the case of World War II. Fournal of Economic History 6o, pp. 468-96.

FRITSCHY, W. (2007). The efficiency of taxation in Holland. In O. Gelderblom (ed.), The Political Economy of the Dutch Republic. London: Ashgate.

FritsCHY, W., T'HART, M. and Horlings, E. (200I). Continuities and discontinuities in Dutch fiscal history, I5I5-I9I3. Mimeo, Thirteenth Economic History Congress. 
FRITSCHY, W. and VAN DER VOORT, R. (I997). From fragmentation to unification: public finance, I700-I9I4. In M. t'Hart, J. Jonker and J. L. van Zanden (eds.), A Financial History of the Netherlands. Cambridge: Cambridge University Press.

Global Financial Database. www.globalfinancialdata.com

GREENE, W. (2000). Econometric Analysis, 4th edn. Upper Saddle River: Prentice-Hall.

HILL, C. (1980). The Century of Revolution, I603-I714. Walton-on-Thames: Nelson. HIRST, D. (1986). Authority and Conflict: England, I603-1658. Cambridge, MA: Harvard University Press.

Hoffman, P. and Norberg, K. (1994). Fiscal Crises, Liberty, and Representative Government, I450-1789. Palo Alto: Stanford University Press.

Hoffman, P. and Rosenthal, J. L. (I997). The political economy of warfare and taxation in early modern Europe: historical lessons for economic development. In J. Drobak and J. Nye (eds.), The Frontiers of the Nerw Institutional Economics. St Louis: Academic Press.

Hohenberg, P. and LeES, L. (1985). The Making of Urban Europe, Iooo-1950. Cambridge, MA: Harvard University Press.

Homer, S. and SYlla, R. (I99I). A History of Interest Rates. New Brunswick, NJ: Rutgers University Press.

JACKSON, H. (1974). A Short History of France from Early Times to 1972. Cambridge: Cambridge University Press.

JONES, J. (1972). The Revolution of 1688 in England. London: Weidenfeld and Nicolson.

KISER, E. and SCHNEIDER, J. (I994). Bureaucracy and efficiency: an analysis of taxation in early modern Prussia. American Sociological Review 59, pp. 187-204.

KInDleberger, C. (1984). A Financial History of Western Europe. London: Allen and Unwin.

LA Porta, R., Lopez-DE-Silanes, F. and ShleIfER, A. (2008). The economic consequences of legal origins. Fournal of Economic Literature 46, pp. 285-332.

LA PorTa, R., LopeZ-DE-Silanes, F., Shleifer, A. and Vishny, R. (i997). Legal Determinants of External Finance. Fournal of Finance 52, I I3I-50.

LA PORTA, R., Lopez-DE-Silanes, F., SHLEIFER, A. and VishnY, R. (I998). Law and finance. Fournal of Political Economy I06, pp. I I I3-55.

La Porta, R., Lopez-DE-Silanes, F., Shleifer, A. and Vishny, R. (I999). The quality of government. Fournal of Law, Economics, and Organization $\mathbf{5}$, pp. 222-79.

Le Moniteur Universel.

Maandelijksche Hollandsche Mercurius.

MAdDISON, A. (2003). The World Economy: Historical Statistics. Paris: OECD.

Mata, E. and VAlerio, N. (2002). Història econòmica de Portugal. Lisbon: Editorial Presença.

MATHIAS, P. and O'BRIEN, P. (I976). Taxation in Britain and France, I7I5-I8IO: a comparison of the social and economic incidence of taxes collected for the central governments. Fournal of European Economic History 5, pp. 60I-50.

MAURO, P., Sussman, N. and YAFEH, Y. (2002). Emerging market spreads: then versus now. Quarterly fournal of Economics 1I7, pp. 695-733.

MEISSNER, C. (2005). A new world order: explaining the emergence of the classic gold standard. Fournal of International Economics 6, pp. 385-406. 
Mitchener, K. and WeIDENMIER, M. (2005). Empire, public goods, and the Roosevelt corollary. Fournal of Economic History 65, pp. 658-92.

MOKYR, J. (1998). The Second Industrial Revolution, I870-19I4. In V. Castronono (ed.), Storia dell'economia Mondiale. Rome: Laterza.

MoKYR, J. (I999). The British Industrial Revolution: An Economic Perspective. Boulder, CO: Westview.

National Accounts of the Netherlands. nationalaccounts.niwi.knaw.nl

NorTH, D. and WeINGAST, B. (I989). Constitutions and commitment: the evolution of institutions governing public choice in seventeenth-century England. Fournal of Economic History 49, pp. 803-32.

O'BRIEN, P. (200I). Fiscal exceptionalism: Great Britain and its European rivals, from Civil War to triumph at Trafalgar and Waterloo. Working Paper 65/oI, London School of Economics.

OBSTFELD, M. and TAYLOR, A. (2003). Sovereign risk, credibility, and the gold standard: 1870-I9I3 versus I925-3I. Economic fournal II3, pp. 24I-75.

PRICE, R. (1993). A Concise History of France. Cambridge: Cambridge University Press.

Prijscourant der Effecten.

QUINN, S. (200I). The Glorious Revolution's effect on English private finance: a microhistory, I680-I705. Fournal of Economic History 6I, pp. 593-6I 5.

Reinhart, C., Rogoff, K. and Savastano, M. (2003). Debt intolerance. Brookings Papers on Economic Activity, I, pp. I-74.

Rosenthal, J. L. (I998). The political economy of absolutism reconsidered. In R. Bates et al. (eds.), Analytic Narratives. Princeton: Princeton University Press.

Rosenthal, J. L. and Wong, R. B. (2007). Warfare and economic growth in China and Europe. Mimeo, University of California, Los Angeles.

SACKS, D. (1994). The paradox of taxation: fiscal crises, parliament, and liberty in England, I450-I640. In P. Hoffman and K. Norberg (eds.), Fiscal Crises, Liberty, and Representative Government, I450-I789. Palo Alto: Stanford University Press.

SARGENT, T. and VELDE, F. (I995). Macroeconomic features of the French Revolution. Fournal of Political Economy I03, pp. 474-518.

Stasavage, D. (2003). Public Debt and the Birth of the Democratic State: France and Great Britain, I688-I789. Cambridge: Cambridge University Press.

STASAVAGE, D. (2005). Cities, constitutions, and sovereign borrowing in Europe, I274-I785. International Organization 61, pp. 489-526.

STONE, L. (1979). The Crisis of the Aristocracy, 1558-I64I. Oxford: Clarendon Press.

SUMMERHILL, W. (2004). Inglorious revolution: political institutions, sovereign debt, and financial underdevelopment in imperial Brazil. Mimeo, University of California, Los Angeles.

SUSSMAN, N. and YAFEH, Y. (2000). Institutions, reforms, and country risk: lessons from Japanese government debt in the Meiji era. Fournal of Economic History 6o, pp. 442-67.

SUSSMAN, N. and YAFEH, Y. (2006). Institutional reforms, financial development, and sovereign debt: Britain, I690-I790. Fournal of Economic History 66, pp. 906-35. 
T'HART, M. (I997). The merits of a financial revolution: public finance, I550-I700. In M. t'Hart, J. Jonker and J. L. van Zanden (eds.), A Financial History of the Netherlands. Cambridge: Cambridge University Press.

Tilly, C. (1990). Coercion, Capital, and European States, 990-1990. Cambridge: Blackwell.

TILLY, R. (I966). The political economy of public finance and the industrialization of Prussia, I8I 5-I866. Fournal of Economic History 26, pp. 484-97.

TILLY, R. (1967). The political economy of public finance and the industrialization of Prussia: a correction. Fournal of Economic History 27, p. 39I.

TorTella, G. (2000). The Development of Modern Spain: An Economic History of the Nineteenth and Twentieth Centuries. Cambridge, MA: Harvard University Press.

Tortella, G. and Comín, F. (200I). The merits of a financial revolution: public finance, I550-I700. In M. Bordo and R. Cortés-Conde (eds.), Transferring Wealth and Power from the Old to the New World: Monetary and Fiscal Institutions in the Seventeenth through the Nineteenth Centuries. Cambridge: Cambridge University Press.

VELDE, F. and WEIR, D. (I992). The financial market and government debt policy in France, I746-I793. Fournal of Economic History 52, pp. I-39.

WEIR, D. (I989). The financial market and government debt policy in France, I746-I793. Fournal of Economic History 52, pp. I-39.

WHITE, E. (I989). Was there a solution to the Ancien Régime's financial dilemma? Fournal of Economic History 49, pp. 545-68.

White, E. (1995). The French Revolution and the politics of government finance, I770-I8I5. Fournal of Economic History 55, pp. 227-55.

WHITE, E. (200I). France and the failure to modernize macroeconomic institutions. In M. Bordo and R. Cortés-Conde (eds.), Transferring Wealth and Power from the Old to the New World: Monetary and Fiscal Institutions in the Seventeenth through the Nineteenth Centuries. Cambridge: Cambridge University Press.

Willard, K., Guinnane, T. and Rosen, H. (I996). Turning points in the Civil War: views from the greenback market. American Economic Review 86, IO०I-I8. WoOldRIDGE, J. (2003). Introductory Econometrics: A Modern Approach, 2nd edn. Mason: Thomson South-Western.

ZANDEN, J. L. VAN and PRAK, M. (2006). Towards an economic interpretation of citizenship: the Dutch Republic between medieval communes and modern nation-states. European Review of Economic History 1o, pp. I I I-45.

ZANDEN, J. L. VAN and RIEL, A. VAN (2004). The Strictures of Inheritance: The Dutch Economy in the Nineteenth Century. Princeton: Princeton University Press.

\section{Appendix I. Sources for the yield data}

The abbreviation GFD denotes the Global Financial Database. For additional details, see the text.

Austria-Hungary. Austrian data on Io-year government bonds were drawn from the GFD. For I874-9, the silver 5s bond was used; for 1880-1913, the gold $4 \mathrm{~s}$ bond. For $1874-9$, monthly data were used to compute yearly 
averages; for 1880-1913, weekly data. Yields were for bonds traded in London.

Belgium. Belgian data on Io-year government bonds were drawn from the GFD. For I 832-44, the 5 percent Belgian bond was used; for I $845-58$, the 4.5 percent bond; for 1859 onwards, the 3 percent bond. For I832-84, monthly data were used to compute yearly averages; for I885-98, biweekly data; for I889-I9I3, monthly data. Note that the resulting yield series matched up closely with annual observations (taken from the last day of trading each year) from Homer and Sylla (I99I). Yields were for bonds traded in Brussels.

Denmark. Danish data on I0-year government bonds were drawn from the GFD. For $182 \mathrm{I}-5$ and $1852-8$, the $5 \mathrm{~s}$ bond was used; for $1825-52$, the $3 \mathrm{~s}$ bond; for $1864-94$ the consolidated $4 \mathrm{~s}$ bond. In 1895 the consolidated $4 \mathrm{~s}$ bond was converted into 3.5 percent consols, which were used through I9I3. Data were unavailable for I859-63. Monthly data were used to compute yearly averages from I82I to I913. Yields were for bonds traded in London.

England. The British series on perpetual government bonds were drawn from the GFD. For $1750-3$, the 3 percent yield on annuities was used. For I754 onwards, the British consol was used, which paid 3 percent until I888, 2.75 percent from 1889 to 1906 , and 2.5 percent from 1907 to 1913. For I750-I879, monthly data were used to compute yearly averages; for I880I9I3, weekly data. Note that the resulting yield series matched up closely with annual observations (taken from the last day of trading each year) from Homer and Sylla (199I). Yields were for bonds traded in London.

France. No single debt instrument akin to the British consol existed in France prior to the nineteenth century, making it difficult to identify 'the' interest rate paid on government loans. Indeed, bonds could be perpetual or finite, redeemable or not, and repudiated when revenues ran thin. The eighteenthcentury yield data that I used were collected by Velde and Weir (I992), who chose the October loan as the French asset that best captured yields on longterm government bonds from 1750 to I793. Prior to I770, the October loan was a private debt of the Compagnie des Indes. From 1770 onwards, it was a perpetual debt of the French government. From I 793 to I796, the Paris Stock Exchange was closed off and on. Data for $1794-1800$ were unvailable, though a perpetual 5 percent consolidated bond was issued in I798. It continued to trade until 1825, when the French central government refunded it and issued a perpetual 3 percent bond, which became the primary government bond until I949. Note that a new bond paying quarterly interest replaced the previous 3 percent one in 1862 . French data for the nineteenth and twentieth centuries were supplied courtesy of Jean-Laurent Rosenthal for I8OI-72 and drawn from the GFD for 1873-1913. For 1750-1879, monthly data were used to compute yearly averages; for 1880-1913, weekly data. Yields were for bonds traded on the Paris Stock Exchange. 
Italy. Italian data on long-term government bonds were drawn from the GFD. The average maturity was six years. For I862-99, the consolidated 5 percent bond was used; for 1900-13, the 3.5 percent consol bond. Monthly data were used to compute yearly averages from 1862 to 1913. Yields were for bonds traded in London.

The Netherlands. Public bonds in the Dutch Republic were issued by several authorities, including the Union itself, provinces, and cities. Joost Jonker, Oscar Gelderblom and Heleen Kole collected the Dutch data for I780I8IO. Prior to 1780 , too little data existed to form a comprehensive series. For I780-95, the source was the Dutch newspaper Maandelijksche Hollandsche, which reported yields on various government bonds from securities auctions in Amsterdam. The Holland and Westfriesland perpetual 2.5 percent bond was selected. Like the October loan in eighteenth-century France, this asset best captured long-term yield levels. For I796-1813, the source was the Dutch newspaper Prijscourant der Effecten. In this case, perpetual 2.5 percent national bonds were used. Data were unavailable for I8I2. In I8I4, the entire national debt, with interest rates ranging from 1.25 to 7 percent, was converted into a single one at a rate of 2.5 percent. The data source for I8I4-I9I3 was the GFD. For I780-96, monthly data were used to compute yearly averages; for 1797-1812, biweekly data; for I8I4-8I, monthly data; for 1882 , biweekly data; for $1883^{-1913}$, weekly data. Note that the resulting nineteenth-century yield series matched up closely with annual observations that came from the Dutch National Accounts. Nineteenth- and twentiethcentury bonds were also traded in Amsterdam.

Portugal. Portuguese data on I0-year government bonds were drawn from the GFD. For I823-95 and I903-I3, the 3 percent bond was used. Data were unavailable for 1903. Monthly data were used to compute yearly averages for I823-1913. Note that the resulting yield series matched up closely with monthly observations gathered by hand from Le Moniteur Universel and The Economist for all available years from I835 to 1870 . Yields were for bonds traded in London.

Prussia. Prussian data on IO-year government bonds from I8I5 to I84I were drawn from the GFD. For 1842-69, however, this source used Bavarian bonds. Prussian data on IO-year government bonds were thus drawn from Homer and Sylla (I99I) during those years. 4s bonds were used, except for I844-52, when $3.5 \mathrm{~s}$ bonds were used due to a lack of data. The Prussian data on Io-year government bonds for I870-I9I3 were also drawn from the GFD. Prussian 4 percent consols were used for 1870-97 and German 3 percent Imperial loans for I898-I9I3. For I8I 5-4I, monthly data were used to compute yearly averages; for $1842-69$, annual data (taken from the last day of trading each year); for I870-80, monthly data, for I88I-I9I3, weekly data. Note that the resulting 
yield series taken from the GFD matched up closely with annual observations (taken from the last day of trading each year) for I8I5-4I and I870-80 from Homer and Sylla (I99I). Yields were for bonds traded in Berlin.

Spain. As in Old Regime France, the Spanish crown issued a variety of disparate debt instruments prior to I8I5 (see Tortella and Comìn 200I). However, the Spanish yields series did not begin until I82I. Data were for Io-year government bonds drawn from the GFD. For I823-36, 5s bonds were used. For I836-8I, $3 \mathrm{~s}$ bonds were used. In I88I, the $3 \mathrm{~s}$ were converted into a I percent bond. In I882, the I percent bond was converted into a I.25 percent one, and later into a 4 percent one. The 4 percent bond was used from I 882 to I9I3. Monthly data were used for I82I-I9I3 to compute yearly averages. Note that the resulting yield series matched up closely with monthly observations gathered by hand from Le Moniteur Universel and The Economist for 1823-70. London yields were used for the entire series except for I9I3 when the Madrid yield was used.

Sweden. Swedish data on Io-year government bonds were drawn from the GFD. For $1868-78$, the 5 s bond was used; for $1878-94$, the $4 \mathrm{~s}$ bond; for I894-I9I3, the 3 s bond. Monthly data were used to compute yearly averages for I868-1913. Note that the resulting yield series matched up closely with annual observations (taken from the last day of trading each year) from Homer and Sylla (I99I) for all available years from I855 to I9I3. Yields were for bonds traded in London.

\section{Appendix 2. Regression variables}

For additional details, see Sections 5 and 6 of the text.

The dependent variable is the spread between the average annual yield on long-term government bonds for each sample country and the average annual yield on the British consol as expressed in basis points.

The dummy variable for fragmented and absolutist political regimes takes a value of one for each year that a sample country possessed a fragmented and absolutist regime from I750 to I9I3. As the benchmark case, I omitted it from the regression specifications. The dummy variable for centralized and absolutist political regimes takes a value of one for each year that a sample country possessed a centralized and absolutist regime from I750 to I9I3. The dummy variable for fragmented and limited political regimes takes a value of one for each year that a sample country possessed a fragmented and limited regime from I750 to I9I3. There is only one such case among sample countries; for additional details, see Section 4 . The dummy variable for centralized and limited political regimes takes a value of one for each year that a sample country possessed a centralized and limited regime from 1750 to I9I3. 
Table AI. European military conflicts, I750-I9I3

\begin{tabular}{|c|c|c|}
\hline Conflict & Year(s) & Combatants \\
\hline Seven Years' War & I756-63 & Ah, Fr, Ru, Sp, Sw v. En, Pt, Pr \\
\hline Corsican War & I $768-9$ & Co v. Fr \\
\hline War of the Bavarian Succession & I $778-89$ & Ah v. $\operatorname{Pr}$ \\
\hline Russo-Swedish War & I $788-90$ & Ru v. Sw \\
\hline War of the Ist Coalition & I $792-7$ & $\mathrm{Ah}, \mathrm{En}, \mathrm{Nl}, \mathrm{Pt}, \mathrm{Pr}, \mathrm{Sp}$ v. Fr \\
\hline War of the 2 nd Coalition & I798-I80I & Ah, En, Pr, Ru, Tr v. Fr, Nl \\
\hline Napoleonic Wars (I803-I8I5) & & \\
\hline War of the 3 rd Coalition & I $805-7$ & Ah, En, Pr, Ru, Sw v. Fr, Nl, Pl \\
\hline Peninsular War & I $807-\mathrm{I} 4$ & $\mathrm{En}, \mathrm{Pt}, \mathrm{Sp}$ v. Fr, Nl \\
\hline Austrian War & I809 & Ah v. Fr, Nl \\
\hline Russian Campaign & I8I2 & Ah, Dk, Ru v. Fr, Nl, Pl \\
\hline Leipzig Campaign & I8I3 & $\mathrm{En}, \mathrm{Pr}, \mathrm{Ru}, \mathrm{Sw}$ v. Fr, Nl \\
\hline Campaign in France & I8I4 & En, Nl, Ru, Pr, Sw v. Fr \\
\hline Austrian Campaign & I8I5 & Ah v. Fr \\
\hline Waterloo Campaign & I8I 5 & $\mathrm{Ah}, \mathrm{En}, \mathrm{Nl}, \mathrm{Pt}, \mathrm{Pr}, \mathrm{Sp}$ v. Fr \\
\hline Russo-Swedish War & I $808-9$ & $\mathrm{Ru}$ v. Sw \\
\hline Riego Rebellion & I823 & Fr v. Sp \\
\hline Belgian War of Independence & $1830-3$ & $\mathrm{Be}, \mathrm{En}, \mathrm{Fr}$ v. Nl \\
\hline Austro-Sardo War & I $848-9$ & Ah v. Sa \\
\hline Ist Italian War of Independence & I $848-9$ & Ah, Fr, Sp v. It \\
\hline Ist Schleswig-Holstein War & I $848-9$ & Dk, Sw v. Pr \\
\hline Crimean War & I $853-6$ & En, Fr, Tr v. Ru \\
\hline Franco-Austrian War & 1859 & Ah v. Fr \\
\hline 2nd Italian War of Independence & I859-6I & Ah v. It \\
\hline 2nd Schleswig-Holstein War & I864 & Ah, Pr v. Dk \\
\hline Austro-Prussian War & 1866 & Ah v. It, Pr \\
\hline Battle of Mentana & I867 & Fr v. It \\
\hline Franco-Prussian War & I870-I & Fr v. Pr \\
\hline Austrian Conquest of Bosnia & I 878 & Ah v. Bo \\
\hline
\end{tabular}

Source: Clodfelter (2002).

Notes: Country abbreviations are Austria-Hungary (Ah), Belgium (Be), Bosnia (Bo), Corsica (Co), Denmark (Dk), England (En), France (Fr), Italy (It), the Netherlands (Nl), Poland (Pl), Portugal (Pt), Prussia (Pr), Russia (Ru), Sardinia (Sa), Spain (Sp), Sweden $(\mathrm{Sw})$ and Turkey $(\mathrm{Tr})$.

The country dummy variable takes a value of one to identify individual sample countries.

Wars and war years are from Clodfelter (2002). All conflicts fought at least in part in Western Europe (as well as those fought at least in part in Eastern Europe so long as they involved at least one sample country) from I750 to I9I3 were included. Table AI provides a complete list.

The default dummy variable takes a value of one for each year that a national government partially or fully defaulted on its publicly held debt from 1750 to 1913 according to Reinhart, Rogoff and Savastano (2003) and Dincecco (2009b). Table A3 provides a complete list. 
Table A2. European civil wars, coups and revolutions, I750-I9I3

\begin{tabular}{|c|c|c|}
\hline & $\operatorname{Year}(\mathrm{s})$ & Event \\
\hline Austria-Hungary & I848 & Year of Revolutions \\
\hline \multirow[t]{2}{*}{ Belgium } & I789-90 & Brabant Revolution \\
\hline & 1830 & Belgian Revolution \\
\hline Denmark & I 848 & Year of Revolutions \\
\hline England & & $\begin{array}{l}\text { No civil war, coup or revolution from } \\
\text { I750 to I9I3 }\end{array}$ \\
\hline \multirow[t]{8}{*}{ France } & I789-99 & French Revolution \\
\hline & I799 & Coup by Napoleon I \\
\hline & I8I5 & Bourbon Restoration \\
\hline & I830 & July Revolution \\
\hline & I 848 & Year of Revolutions \\
\hline & I85I & Coup by Napoleon III \\
\hline & I870 & Fall of 2 nd empire \\
\hline & I87I & Paris Comune \\
\hline Italy & & $\begin{array}{l}\text { No civil war, coup, or revolution from } \\
\text { I } 86 \text { I to I } 9 \text { I3 }\end{array}$ \\
\hline \multirow[t]{4}{*}{ Netherlands } & 1785 & Batavian Revolution \\
\hline & I $8 \mathrm{I} 4-\mathrm{I} 5$ & Establishment of Dutch Kingdom \\
\hline & I830 & Belgian Revolution \\
\hline & I848 & Year of Revolutions \\
\hline \multirow[t]{11}{*}{ Portugal } & I808 & Revolution of 1808 \\
\hline & I 820 & Revolution of 1820 \\
\hline & I $820-3$ & Ist Civil War of Portuguese Revolution \\
\hline & I823 & Coup of 1823 \\
\hline & I $827-8$ & Miguelite Insurrection \\
\hline & I $832-4$ & 2nd Civil War of Portuguese Revolution \\
\hline & I836 & Coup of I 836 \\
\hline & I $846-7$ & 3rd Civil War of Portuguese Revolution \\
\hline & I849 & Costa Cabral Coup \\
\hline & I85I & Saldanha Coup \\
\hline & I9IO & Establishment of ist Portuguese Republic \\
\hline Prussia & I 848 & Year of Revolutions \\
\hline \multirow[t]{10}{*}{ Spain } & 1820 & Coup of 1820 \\
\hline & I823 & Restoration of 1823 \\
\hline & I833-9 & Ist Carlist War \\
\hline & I 843 & Moderate Coup \\
\hline & I $847-9$ & Matiners' (2nd Carlist) War \\
\hline & I 854 & Rebellion of I 854 \\
\hline & I863 & Government collapse of 1863 \\
\hline & I $868-70$ & Glorious Revolution \\
\hline & I872-6 & $\begin{array}{l}\text { 3rd Carlist War (encompasses the } \\
\text { Restoration of } 1874 \text { ) }\end{array}$ \\
\hline & I909 & La Semana Trágica \\
\hline \multirow[t]{3}{*}{ Sweden } & 1772 & Coup of 1772 \\
\hline & I 792 & Assassination of Gustav III \\
\hline & 1809 & Coup against Gustav IV \\
\hline
\end{tabular}

Source: Dincecco (2009a). 
Table A3. Defaults in Europe, I750-1913

\begin{tabular}{ll}
\hline \hline & Year \\
\hline Austria-Hungary & I802, I805, I8I I, I8I6, I868 \\
England & No defaults from I750 to I9I3 \\
France & I759, I770, I788, I797 \\
Netherlands & I8I0 \\
Prussia & I807, I8I3 \\
Spain & I820, I83I, I834, I85I, I867, I872, I882 \\
Belgium & No defaults from I83 I to I9I3 \\
Denmark & No defaults from I8I5 to I9I3 \\
Italy & No defaults from I86I to I9I3 \\
Portugal & I837, I84I, I845, I852, I890 \\
Sweden & No defaults from I8I5 to I9I3 \\
\hline \hline
\end{tabular}

Sources: Reinhart, Rogoff and Savastano (2003) and Dincecco (2009b).

The deficit variable, taken from Dincecco (2009b), is the budget deficitto-revenue ratio for each sample country for each available year from 1750 to I9I3.

The dummy variable for civil wars, coups and revolutions takes a value of one for each year of civil war, coup or revolution within sample countries from 1750 to 1913 according to Dincecco (2009a). Table A2 provides a complete list. Insurrections, massacres, riots and uprisings were generally not included.

The urbanization variable calculates the urban population as a fraction of the total population for each sample country annually. All urban population figures are from De Vries (1984). Figures for 1750 and 1800 are from appendix 3, pp. 305-37, and figures for 1850 , 1890 and 1980 are from table 4.8 , pp. $44-7$, for cities with populations of at least I0,000 inhabitants through 1850 , with at least 20,000 inhabitants in 1890 , and with at least I00,000 inhabitants in 1980. All intermediate years were interpolated. De Vries provides urbanization figures for Germany rather than for Prussia and for Scandinavia rather than for Denmark or Sweden. Urbanization figures for Austria-Hungary include Bohemia. For country population sources, see Dincecco (2009a).

The per-capita GDP variable, which comes from Maddison (2003), takes the natural logarithm of per-capita GDP in 1990 international Geary-Khamis dollars for sample countries from I750 to I9I3. Data were available for I700 and I820-I9I3. All intermediate years were interpolated. Maddison provides per-capita GDP figures for Germany rather than for Prussia.

The gold variable dummy variable takes a value of one for each year that a country was on gold according to Meissner (2005), who employs a strict measure of gold adherence that chooses the year in which a currency became 
de facto and de jure convertible into gold. Adoption years were England, I821; Portugal, I854; Prussia, I872; Denmark, I873; Sweden, I873; the Netherlands, I875; Belgium, I878; France, I878; and Italy, I884. Neither Austria-Hungary nor Spain formally adopted the gold standard prior to I9I3.

The average spread variable is the average yield spread in basis points for all available sample countries over the 'safe' British consol for each year from I750 to I9I3. 